\title{
The gig economy: a hypothetical contract analysis
}

\author{
Marc T. Moore*
}

Faculty of Law, University of Cambridge

Gig work and other flexible labour practices have been subject to unprecedented levels of attention recently. While this topic has attracted significant interest from employment lawyers, it remains relatively underexplored from other pertinent legal and inter-disciplinary angles. This article will adopt an alternative perspective on flexible work inspired by Coase's theory of the firm. Focussing on the implications of flexible work for the relative allocation of control, risk and reward within the firm, it will highlight how both task-oriented ('gig') and on-demand ('casual') work practices typically entail workers assuming most of the positional disadvantages associated with orthodox employment and self-employment, while enjoying none or few of the corresponding advantages. Using a hypothetical contract analysis, it will highlight the structural similarity between flexible work and unsecured financial investments in business firms by reference to key strands of institutional economics and law \& finance literature. On this basis, it will enquire as to optimal forms of compensation that rational flexible workers can (counter-factually) be regarded as bargaining for in the absence of

With thanks to Andrew Johnston, Andreas Kokkinis and Wanjiru Njoya for their close readings of, and insightful comments on, an earlier version of this article. The author is further grateful for comments received at various seminars/workshops where earlier versions of this article have been presented, including at the University of Cambridge, the University of Sheffield and Kingston University London. Thanks are especially due in this regard to Zoe Adams, Simon Deakin, Jeremias Prassl, Michael Wynn, Ting Xu and Frank Zhang. Thanks also to the anonymous Legal Studies reviewer who provided additional valuable suggestions. The usual disclaimers apply. 


\section{The Gig Economy}

impediments to efficient contracting, and as the price for trading off their traditional employment guarantees.

Keywords: flexible work, gig economy, law and economics, Coase, employment law, corporate governance.

Marc Moore, Reader in Corporate Law, University of Cambridge, Murray Edwards College, New Hall, Huntingdon Road, Cambridge CB3 ODF, UK.Email:mtm48@cam.ac.uk. 


\section{The Gig Economy}

\section{INTRODUCTION}

As of late, the terms 'flexible work' and 'gig economy' have acquired at least as many negative connotations as positive ones. ${ }^{1}$ While some intuitively associate these notions with organisational innovation, individual empowerment and flexible work-life balance, ${ }^{2}$ for others they are emblematic of rampant worker exploitation, individual vulnerability and persistent economic insecurity. ${ }^{3}$ Although the main forms of flexible work practice observed in today's economy are by no means novel phenomena, both casual and gig-based work arrangements have undoubtedly been subject to unprecedented levels of attention recently.

Arguably the principal reason for the increased attention devoted to such practices today has been the widely-reported usage by many well-known corporate employers of socalled 'zero-hours' contracts, which are commonly perceived as denying workers any basic level of security with respect to employment tenure or continuing receipt of work income. ${ }^{4}$ The enhanced public salience of flexible work practices is additionally attributable to high-profile

\footnotetext{
${ }^{1} \mathrm{~J}$ Prassl Humans as a Service: The Promise and Perils of Work in the Gig Economy (Oxford: OUP, 2018), pp 23; B Rogers 'The Social Costs of Uber' (2015) 82 U Chi L Rev 85, at 85-86.

${ }^{2}$ M Taylor Good Work: The Taylor Review of Modern Working Practices (July 2017), p. 7, available at https://www.gov.uk/government/publications/good-work-the-taylor-review-of-modern-working-practices ; Department for Business, Energy \& Industrial Strategy (BEIS) Good Work: A response to the Taylor Review of Modern Working Practices (February 2018), pp 5, 12, available at https://www.gov.uk/government/publications/government-response-to-the-taylor-review-of-modern-workingpractices

${ }^{3}$ AG Haldane (Bank of England), 'Work, Wages and Monetary Policy' (speech from 20 June 2017), at 4, available at https://www.bankofengland.co.uk/speech/2017/work-wages-and-monetary-policy; BEIS, ibid, p 10.

${ }^{4}$ Chartered Institute of Personnel and Development (CIPD), Zero-hours and short-hours contracts in the UK: Employer and employee perspectives (December 2015), available at https://www.cipd.co.uk/Images/zero-hoursand-short-hours-contracts-in-the-uk_2015-employer-employee-perspectives_tcm18-10713.pdf
} 
UK employment tribunal and court cases on alleged employer exploitation of gig economy workers. Indeed, the question of whether gig economy operatives should be classified, for employment protection purposes, as either workers or independent contractors has proved to be one of the most vexing legal and public policy concerns of recent times, and has prompted a rapidly growing line of judicial decisions on the question of bogus self-employment. ${ }^{5}$ The above issues were also the fulcrum of the government-commissioned Taylor Review of Modern Working Practices ${ }^{6}$ in 2017 and the subsequent report of the House of Commons Work and Pensions and Business, Energy and Industrial Strategy Committees ${ }^{7}$ into the same matter, which presently look set to prompt significant reform to key aspects of UK employment law. ${ }^{8}$

It is not the purpose of this article to undertake any sort of detailed technical analysis of these legal and regulatory developments, which have already been (and no doubt will continue to be) subject to rigorous critique elsewhere. ${ }^{9}$ Above all, the evolving approach of

\footnotetext{
${ }^{5}$ See eg Uber v Aslam [2018] EWCA Civ 2748; Pimlico Plumbers v Smith [2018] UKSC 29; Uber v Aslam, Appeal No UKEAT/0056/17/DA (10 November 2017); Independent Workers' Union of Great Britain (IWGB) v RooFoods Limited T/A Deliveroo, Case No TUR1/985 (14 November 2017); Gascoigne v Addison Lee Ltd, Case
} No 2200436/2016 (14 August 2017); Dewhurst v CitySprint UK Ltd, Case No ET/2202512/2016 (5 January 2017). In the US context, meanwhile, see Dynamex Operations West, Inc. v Superior Court, Ct App 2/7 B249546 (30 April 2018).

${ }^{6}$ See Taylor, above n 2.

${ }^{7}$ See House of Commons, Work and Pensions and Business, Energy and Industrial Strategy Committees (HC Committees) A framework for modern employment (Second Report of the Work and Pensions Committee and First Report of the Business, Energy and Industrial Strategy Committee of Session 2017-19) (November 2017), available at https://publications.parliament.uk/pa/cm201719/cmselect/cmworpen/352/352.pdf

${ }^{8}$ See Department for Business, Energy \& Industrial Strategy, Good Work Plan (December 2018), available at https://www.gov.uk/government/publications/good-work-plan/good-work-plan

${ }^{9}$ See eg K Bales, A Bogg and T Novitz "Voice" and "Choice" in Modern Working Practices: Problems With the Taylor Review' (2018) 47 ILJ 46. 
tribunals and courts to determining the presence of employer direction and control over appbased gig workers, along with the implications of the Taylor Review's proposed new 'dependent contractor' status, ${ }^{10}$ are likely to command the considerable and sustained attention of employment lawyers over the coming months and even years. In acknowledgement of this fact, and with a view to further enriching the conceptual soil for such debates, the present article deliberately seeks to chart an alternative methodological course with respect to the topic at hand, one which is likely more redolent of established corporate rather than employment law scholarship.

Drawing on key concepts from law and economics literature and, in particular, Ronald Coase's classic work on the economic nature of the business firm, this article seeks to position the main forms of flexible work within a broader institutional frame of reference. Accordingly, it focuses principally on the implications of task-oriented and on-demand work in terms of the relative allocation of control, risk and reward within the firm. From this perspective it will highlight how both task-oriented and on-demand work arrangements typically entail workers assuming a significant degree of residual economic exposure to product market uncertainty and other exogenous shocks, absent any corresponding compensation in the form of enhanced contractual, proprietary or governance entitlements. ${ }^{11}$ From an employer point of view, flexible (and especially zero-hours) work is thus a hybrid phenomenon that combines the most favourable features of both firm and market centred forms of human capital allocation. However, from a worker perspective the opposite will frequently be the case.

\footnotetext{
${ }^{10}$ See Taylor, above n 2, pp 35-36; HC Committees, above n 7, paras 11-15; BEIS, above n 2, p 30.

${ }^{11}$ In this regard, the Taylor Review asserts that 'flexibility must not be one-way with individuals absorbing all of the risk', and emphasises the centrality to effective employment relations of what it terms 'the underlying principle of power balance'. See Taylor, above n 2, p 34.
} 
Adopting a hypothetical contract analysis (likewise inspired by Coase's work), the article will subsequently enquire as to optimal forms of quasi-contractual compensation that rational flexible workers can (counter-factually) be regarded as bargaining for in the absence of material impediments to efficient contracting, and as the notional price for trading off their traditional employment guarantees. The aim of this enquiry is to provide fresh normative insights into what is already a highly fertile field for legal-academic analysis, with a view to enhancing the inter-disciplinarity and conceptual sophistication of future scholarly debates and regulatory reform initiatives. The discussion accordingly proceeds as follows.

The article begins by highlighting the key characteristics of the two orthodox forms of productive human capital allocation from a Coasean firm-theory perspective, namely employment and self-employment. However, whereas Coase analysed the distributive implications of the employment relation more or less exclusively from the human capital user (i.e. employer) side of the picture, this article focuses instead on the distributive consequences of employment (vis-à-vis self-employment) for the relevant human capital supplier (i.e. employee). Next, it extends this analysis by reference to two of the principal forms of human capital provision that lie between these extremes, namely task-oriented ('gig') and on-demand ('casual') work, identifying their respective similarities to, and also differences from, employment and self-employment in the traditional sense. On this basis, it then develops a hypothetical bargaining model geared to determining the notionally ideal means of compensating flexible workers for their assumption of residual business risk exposure and associated positional costs, in particular by drawing a structural comparison between: on the one hand, key forms of flexible or non-standard work; and, on the other, 'at-risk' or unsecured financial investments in business firms. Finally, it provides some concluding observations. 


\section{EMPLOYMENT v SELF-EMPLOYMENT AS COMPETING FORMS OF}

\section{PRODUCTIVE HUMAN CAPITAL ALLOCATION}

In his classic 1937 article 'The Nature of the Firm', ${ }^{12}$ the economist Ronald Coase ${ }^{13}$ contrasted the key characteristics of markets and firms as the basic institutional means of allocating human capital within productive activity. ${ }^{14}$ Accordingly, Coase reasoned that an entrepreneur, in determining how to obtain the necessary factors of production for her business, is in the simplest case faced with a choice between two alternatives. ${ }^{15}$

\footnotetext{
${ }^{12}$ See RH Coase 'The Nature of the Firm' (1937) 4 Economica 386.

${ }^{13}$ Admittedly, the present article is by no means the first to apply Coasean theory in analysing features of the contemporary gig economy and other flexible work practices. For earlier examples, see Rogers, above n 1; O Lobel ‘Coase \& the Platform Economy’ (2017) University of San Diego School of Law Research Paper No 17 -
} 318; J Tomassetti 'Does Uber Redefine the Firm? The Postindustrial Corporation and Advanced Information Technology’ (2016) 34 Hofstra Lab \& Emp LJ 1. However, whereas previous such analyses have focused primarily on the implications of task-oriented work for productive coordination, transaction costs reduction and/or labour standards, this article's analysis is centred instead on the ramifications of flexible work practices more generally in terms of the relative attribution of control, risk and profit between employers and workers. It thus seeks to provide a broader and more multi-dimensional institutional analysis of flexible work practices than those previous works, using conceptual tools adopted principally from corporate law (as opposed to labour law) scholarship.

${ }^{14}$ Tomassetti, ibid, at 17-18.

${ }^{15}$ On the firm/market dichotomy generally, see also OE Williamson 'The Economics of Internal Organization: Exit and Voice in Relation to Markets and Hierarchies' (1976) 66 AER 369, at 369; AD Chandler The Visible Hand: The Managerial Revolution in American Business (Cambridge, MA: Harvard University Press, 1977), p 11; and, in the specific context of informationally and/or technologically intensive markets, see CU Ciborra 'Markets, Bureaucracies and Groups in the Information Society' (1983) 1 Information Econ \& Policy 145, at 148; T Malone, J Yates and RI Benjamin 'Electronic Markets and Electronic Hierarchies' (1987) 30 Commun ACM 484, at 485 . 
One option is for the entrepreneur to conduct her business purely by way of the open market, obtaining each factor of production that she requires by way of ad hoc negotiation with various suppliers. If the entrepreneur is dependent exclusively on physical capital (e.g. premises, equipment and/or stock in trade) to sustain her business operations, and is both able and willing to supply all of the necessary human capital (i.e. labour or manpower) herself, then such a strategy makes perfect sense. But if the entrepreneur is reliant to a significant extent on the labour of others for her productive activities, then a purely market centred approach to hiring human capital becomes much more difficult to sustain.

In theory the entrepreneur could conceivably still opt to obtain all of the human capital she needs on a decentralised market basis, by negotiating a discrete (or 'spot') supply contract every time she requires a particular productive, logistical or administrative task fulfilled within her business (or at least one that she is unable or unwilling to carry out herself). Almost certainly the more rational option in this scenario, though, would be for her simply to enter into a few longer-term and relatively indiscrete (i.e. open-ended) contracts with certain trusted human capital suppliers, under which they each agree to submit to the authority and direction of the entrepreneur within contractually agreed bounds. ${ }^{16}$

From the point of view of allocating human capital in the service of productive activity, the institution known as 'employment' thus essentially entails supplanting the price mechanism of the outside labour market with an alternative hierarchical coordination mechanism known as 'the firm'. ${ }^{17}$ Accordingly, within the ambit of the employment relation the input-provider (as employee) becomes subject to the discretionary prerogative of her employer on a continuing

\footnotetext{
${ }^{16}$ Coase, above n 12, at 391; HA Simon 'A Formal Theory of the Employment Relationship' (1951) 19 Econometrica 293, at 293-94.

${ }^{17}$ Coase, ibid, at 392.
} 
basis. ${ }^{18}$ This obviates the considerable transaction costs her employer would otherwise have to incur to obtain the same degree of labour by way of a series of individual task-based contracts with outside human capital suppliers. ${ }^{19}$

Such may be the case from the human capital hirer (or employer)'s point of view, but what about from the perspective of the human capital supplier? Curiously, Coase seemed to devote less direct consideration to the latter issue. Notwithstanding, the essential nature of the corresponding dilemma confronting the latter party to the relation can readily be surmised as follows.

On the one hand the human capital supplier might opt to set up as an entrepreneur or firm owner herself, thereby providing her labour (or, more accurately, the goods or services produced or supplied via her labour) directly on the open market and independently of any superior employer coordination or oversight. Accordingly, the human capital supplier (as entrepreneur) will purchase or hire the necessary physical capital and ancillary human capital (e.g. logistical or administrative work) to support her in her productive activities, while retaining the ultimate power of direction over her work along with the associated ownership right to appropriate the residual profit of her business. ${ }^{20}$ At the same time she will have the unbridled right to diversify her human capital as widely or as narrowly as she chooses, subject only to the obvious extraneous limitations of physical and market capacity. Quid pro quo, the human capital supplier (as entrepreneur) will undertake to bear the ensuing residual risk of loss in the event that her business venture either fails or is lossmaking, including the inevitable depreciation and replacement costs incurred in connection with any physical capital which she owns. However, this will be counterbalanced by her corresponding capacity - as residual firm

\footnotetext{
${ }^{18}$ Simon, above n 16, at 294.

${ }^{19}$ Coase, above n 12 , at $390-91$.

${ }^{20}$ This is what Coase refers to as 'the advantage of "being one's own master".' Ibid, at 390.
} 
controller - to wield a determinative influence over the firm's business strategies and, in particular, its prevailing disposition towards risk taking. ${ }^{21}$ On the other hand, the human capital supplier (as entrepreneur) will have no ex ante contractual guarantee of paid work in the vein of an orthodox employee, but rather will be compelled to seek out prospective 'purchasers' of her labour directly on the open market while absorbing the ongoing search, negotiation and other costs that this entails. Alternatively, the same human capital supplier might well decide (assuming that the opportunity is available to her) in effect to opt out of the open market altogether, by providing her labour instead within the context of a unitary employment (or firm) relation. The upsides to her of doing so are readily apparent. In the orthodox employment relation, the human capital supplier (as employee) is promised a pre-agreed rate of remuneration by her employer for the duration of the working relationship, and irrespective of interim changes in the relevant market environment. ${ }^{22}$ The employee consequently enjoys a degree of relative immunity from residual business risk, insofar as her rate of return on human capital is - at least in the immediate term - unaffected by adverse product market and other extraneous developments. ${ }^{23}$ Finally, the employee enjoys additional immunity from human

\footnotetext{
${ }^{21}$ On the notion of residual risk exposure as a justificatory basis for allocating ultimate firm ownership rights, see L Putterman 'Ownership and the Nature of the Firm' (1993) 17 J Comp Econ 243, at 246-48; FE Easterbrook and DR Fischel The Economic Structure of Corporate Law (paperback ed) (Cambridge, MA: Harvard University Press, 1996; first published 1991), pp 67-68.

${ }^{22}$ A Sundararajan The Sharing Economy: The End of Employment and the Rise of Crowd-Based Capitalism (Cambridge, MA: MIT Press, 2016), p 11.

${ }^{23}$ This is what Deakin and Wilkinson refer to as the 'risk function' of the orthodox employment contract, whereby 'it channels the risks of economic insecurity in such a way as to protect the individual worker against the consequences of that very same dependence on, and subordination to, the employer's superior resources.' See $\mathrm{S}$ Deakin and F Wilkinson The Law of the Labour Market: Industrialization, Employment, and Legal Evolution (Oxford: OUP, 2005), p 109. On this, see also Prassl, above n 1, p 131.
} 
capital-redeployment costs insofar as her relative security of income obviates the need to seek alternative buyers for her labour (or, rather, the product(s) thereof) on the outside market for services.

Of course these valuable immunities do not come for free,${ }^{24}$ but rather are gained at the corresponding cost (for the human capital supplier) of having to submit her labour to the ultimate direction and oversight of an employer. ${ }^{25}$ This typically entails the employee surrendering determinative control over not just what she does 'on the job', in the sense of what specific work tasks she performs and how she carries them out. ${ }^{26}$ It also tends to involve the employee ceding a significant degree of her 'off the job' freedom, to the extent that her obligation to be available during specified working hours has the effect of restricting her practical capacity for diversification of human capital across different and unrelated work

\footnotetext{
${ }^{24}$ In this regard, orthodox (i.e. guaranteed-hours) employment represents a form of risk insurance insofar as the employee indirectly 'pays' the employer (in the manner outline below) for directly assuming a greater share of the risk to which the continuing value of the employee's human capital would otherwise be exposed, and which the employer is better positioned to bear efficiently on account of their typically greater wealth. On the general function of insurance as a mechanism for efficient risk-sharing in this way, see KJ Arrow 'The Theory of RiskBearing: Small and Great Risks' (1996) 12 J Risk Uncertain 103, at 104; FH Knight Risk, Uncertainty and Profit (Orlando: Signalman, 2009; first published 1921), p 21. On the impact of modern flexible labour practices in effectively reallocating a significant share of risk back on to workers, and thereby undermining the efficient riskpooling function that would otherwise be assumed by better-resourced corporate employers, see JS Hacker The Great Risk Shift: The New Economic Insecurity and the Decline of the American Dream (Oxford: OUP, 2006), pp 66-68.

${ }^{25}$ Simon, above n 16, at 294. Deakin and Wilkinson describe this as the 'coordination function' of the employment contract, whereby 'it expresses the worker's subordination to the managerial power of the employer within the enterprise'. See above n 23; Z Adams and S Deakin 'Institutional Solutions to Precariousness and Inequality in Labour Markets' (2014) 52 BJIR 779, at 786.

${ }^{26}$ Coase, above n 12 , at 392.
} 
outlets. Furthermore, with her relative immunity from residual business risk exposure comes the employee's corresponding exclusion from the management and governance of the firm, such that the employee (at least qua employee) is ordinarily denied the right to influence the strategic direction of her employer's business and - relatedly - its prevailing risk appetite. ${ }^{27}$

In Coasean terms, therefore, the transition from human capital entrepreneurship to employment entails the relevant capital provider effectively 'trading off' her rights to control and diversification of human capital, in return for relative insulation from residual business risk exposure and capital-redeployment costs. Moreover, as the employee (unlike the human capital entrepreneur) is no longer the ultimate owner of the business in which her labour is employed, it goes without saying that she ordinarily enjoys no converse upside right either to appropriate any share of residual business profit, or to influence the overall strategic direction and risk appetite of the firm's business. The essential distinctions between these two typical economic role definitions can accordingly be summarised in the following basic typology.

\section{Table 1: INSERT TABLE 1 ABOUT HERE}

\section{TASK-ORIENTED AND ON-DEMAND WORK AS HYBRIDISED FIRM/MARKET PHENOMENONA}

The Coasean distinction between employment and self-employment as competing forms of productive human capital allocation is highly instructive. However, at least in its basic form the model is ultimately one of extreme types; whereas, in reality, the variation between the two phenomena is typically a sliding scale of multiple hybrid forms, as opposed to a stark binary

\footnotetext{
${ }^{27}$ Putterman, above n 21, at 248; L Putterman 'On Some Recent Explanations of Why Capital Hires Labour' (1984) 22 Econ Inq 171.
} 
dichotomy. ${ }^{28}$ Meanwhile, the economic actors typically employed in such intermediate roles today can vary from the one extreme of the occasional student gig worker seeking additional income for leisure activities, to the sole-occupation zero-hours contractor looking for an adequate level of monthly income to house, feed and/or clothe herself and her dependents. ${ }^{29}$

However, a uniting feature of all such atypical work arrangements, notwithstanding their significant differences, is the fact that they commonly exhibit some combination or other of certain elements of employment and self-employment in the traditional sense of the terms. As such they are aptly characterised as hybrid ${ }^{30}$ (or, perhaps more appropriately given the usual bargaining dynamics involved, hybridised) firm/market phenomena. ${ }^{31}$ Moreover, broadly speaking it is possible to delineate two particularly common hybridised quasi-employment forms in this regard, namely: (i) task-oriented (or 'gig') work, and (ii) on-demand (or 'casual') word. As will be explained further below, whereas the former type of work tends to exhibit many (albeit by no means all) characteristic features of market-centred human capital allocation (i.e. self-employment) in the Coasean sense; the latter is typically much more akin to standard firm-centred human capital allocation (i.e. employment), at least insofar as its negative (or 'downside') payoffs for the relevant worker are concerned.

\section{(a) Task-oriented ('gig') work}

\footnotetext{
${ }^{28}$ On this generally, see OE Williamson Markets and Hierarchies: Analysis and Antitrust Implications (New York: The Free Press, 1975).

${ }^{29}$ On this, see RSA Good Gigs: A fairer future for the UK's gig economy (2017), Section 1, available at https://www.thersa.org/globalassets/pdfs/reports/rsa_good-gigs-fairer-gig-economy-report.pdf

${ }^{30}$ Prassl, above n 1, p 19.

${ }^{31}$ Although for a competing characterisation of gig economy employment models (at least in the app-based private transportation market) as a means of simply reinforcing existing firm-based authority structures by facilitating lower-cost productive coordination by employers, see Tomassetti, above n 13, at 21-30.
} 
The term 'gig economy' is often used today in a broad sense to denote what is widely perceived as a contemporary labour market climate dominated in large part by short-term and insecure working arrangements. ${ }^{32}$ However, this is something of a misnomer. Strictly speaking, the notion of 'gig' work refers specifically to task-oriented or 'piece' work: ${ }^{33}$ that is, where a worker receives payment for the performance of discrete and divisible single functions such as individual taxi journeys, goods deliveries or domestic tasks. ${ }^{34}$ This is in contrast to the scenario where the worker subjects herself generally to the directions or orders of an employer over an agreed time period, as in the case of traditional wage labour. ${ }^{35}$

The term is also commonly used in a more specific sense today to denote the purchase and sale of divisible labour online by way of smartphone and tablet apps, ${ }^{36}$ such that it is tempting to see gig work as being one of the peculiar social products of the modern digital age. But despite its vogue present-day connotations, the notion of the gig economy - in the sense of a productive paradigm characterised to a large extent by granular, task-oriented work - is by

\footnotetext{
${ }^{32}$ Indeed, one particularly popular (and seemingly unattributed) definition of the term 'gig economy' as used in online sources is 'a labour market characterised by the prevalence of short-term contracts or freelance work, as opposed to permanent jobs.' See eg B Wilson 'What is the "gig”' economy?', BBC News, 10 February 2017.

${ }^{33}$ L Hook 'Year in a word: Gig economy', Financial Times, 29 December 2015.

${ }^{34}$ RSA, above n 30, p 10. On the characteristic task-divisibility of gig-based work, see Lobel, above n 13, at 4, 12; Sundararajan, above n 22, pp 172-73.

35 M Moore 'Reconstituting Labour Market Freedom: Corporate Governance and Collective Worker Counterbalance' (2014) 43 ILJ 398, at 408-09; S Deakin and F Williamson 'Labour Law and Economic Theory: A Reappraisal' in H Collins, P Davies and R Rideout (eds) Legal Regulation of the Employment Relation (Alphen aan den Rijn: Kluwer, 2000) ch 2, at 42-43; P Selznick, Law, Society and Industrial Justice (New York: Russell Sage Foundation, 1969), p 124.

${ }^{36}$ It has been recorded that the number of workers selling their labour in this way in the UK, whether as sole or partial employment, is estimated at 1.3 million (or $4 \%$ of all those in employment). See Taylor, above n 2 , p 25.
} 
no means a novel phenomenon. ${ }^{37}$ In fact, far from it, the notion long predates the dawn of industrial capitalism itself, and has its roots in the elementary homeworking practices of the pre-Victorian craft and textile trades. ${ }^{38}$

Although task-oriented or 'gig' work in the above sense takes many and varied forms today, the most well-documented examples of such arrangements tend to share some common structural characteristics. These features, moreover, are remarkable when examined from the perspective of the Coasean market $\mathrm{v}$ firm (or self-employment $\mathrm{v}$ orthodox employment) dichotomy. One of the most noteworthy characteristics of task-oriented work, which is intrinsic to its very nature, is that it entails no obligation on the part of the employer to ensure the continuing availability of paid work for the duration of the work relation. Rather, ongoing work-availability (from the worker's perspective) is dependent entirely on the prevailing level of demand for their labour within the relevant geographic or other spatial locality.

The worker's ability to sustain their anticipated rate of return on human capital is consequently rendered directly contingent on preservation of existing product market conditions, meaning that they are continuously exposed to the residual risk of future adverse change in this regard (e.g. as a result of increased supply of the same labour and/or developments precipitating reduced market demand for the relevant service). ${ }^{39}$ Moreover, insofar as gig workers are customarily expected to commit their own physical (as well as

\footnotetext{
${ }^{37}$ Prassl, above n 1, p 72.

${ }^{38}$ Haldane, above n 3, at 9; Prassl, above n 1, pp 74-75, citing M Finkin 'Beclouded work, beclouded workers in historical perspective’ (2016) 37 Comp Lab L \& Pol'y J 603.

${ }^{39}$ On the notion of residual risk exposure generally (and with particular regard to its application to certain types of worker), see G Kelly and J Parkinson 'The Conceptual Foundations of the Company: a Pluralist Approach' in A Gamble, G Kelly and J Parkinson, The Political Economy of the Company (Oxford: Hart, 2000), ch 6; MM Blair Ownership and Control: Rethinking Corporate Governance for the Twenty-First Century (Washington, DC: Brookings Institution, 1995).
} 
human) capital to the relevant enterprise (e.g. a private car, van or bicycle in the case of a gigbased taxi or delivery firm, or self-purchased tools or other equipment in the case of a gigbased service firm),${ }^{40}$ they are further exposed to the depreciation and replacement costs associated with personal ownership of those assets. ${ }^{41}$ By contrast, the orthodox employee enjoys relative buffering from residual business risk via a combination of: (i) the continuing contractual guarantee of a certain level of paid work for the duration of the employment relation, irrespective of interim fluctuations in prevailing market equilibria; and also (ii) her employer's ownership of the principal physical capital deployed in the business, together with the accompanying exposure to asset depreciation and replacement costs. ${ }^{42}$

The task-oriented worker is further compelled to absorb ongoing human capital redeployment costs to the extent that any anticipated shortfall in labour income must be offset by additional income from other sources of work. It follows that, at least insofar as her exposure to residual business risk and human capital redeployment costs is concerned; the task-oriented worker is much more akin to a human capital entrepreneur ${ }^{43}$ than the orthodox employee of the Coasean model. As regards compensation for her labour the task-oriented worker is customarily entitled to a price for each individual task performed, with the applicable rate of pay determined unilaterally by the employer. While this enables the worker (like an entrepreneur) to appropriate a level of income in direct proportion to the extent of her committed labour, the employer nonetheless typically retains the capacity to appropriate

\footnotetext{
${ }^{40}$ Prassl, above n 1, p 60.

${ }^{41}$ Tomassetti, above n 13, at 70; Sundararajan, above n 22, p 159.

${ }^{42}$ However, on the effect of task-oriented and other non-standard employment methods in attenuating (if not removing outright) this notional risk buffer for workers, see Hacker, above n 24, 66.

${ }^{43}$ On this notion generally, see ibid, pp 161-62.
} 
surplus firm value over and above the worker's pre-determined share. ${ }^{44}$ The worker is consequently denied the right to appropriate residual business profit as reciprocal 'upside' compensation for absorbing its 'downside' residual risk. ${ }^{45}$

Additionally, unlike the human capital entrepreneur of the Coasean model, the taskoriented worker normally has no right to influence the running of the overall business in which her labour is employed. Insofar as this precludes the worker from influencing the firm's prevailing risk appetite, it means that the worker's continuing risk-adjusted rate of return on human capital is (indirectly) subject to variation at the unilateral prerogative of the employer. In economic terms this represents an uncompensated social cost that the task-oriented worker is compelled to bear, which - moreover - is impossible for her to price ex ante (e.g. via a correspondingly higher agreed piece rate for her work) due to the inherent uncertainty and indeterminacy of the various market dynamics and other factors at play. ${ }^{46}$

Moreover, in numerous reported instances it would appear that task-oriented workers do not even have meaningful control over the allocation of their human capital itself, let alone the direction of the overall business enterprise in which it is employed. Indeed, as controversial recent cases on the legal classification of gig workers have demonstrated, many gig workers are still subject to significant employee direction and/or control regarding specifically how,

\footnotetext{
${ }^{44}$ Indeed, in the recent Uber Employment Tribunal case (at first instance), the Tribunal rejected Uber's submission that individual taxi drivers using its app were in themselves each operating as independent small businesses, on the premise that the only way for an Uber driver to 'grow' their notional 'business' under the operating conditions imposed on them is simply to spend more hours driving. See Aslam v Uber, Case No 2202550/2015 (29 October 2016), para 90.

${ }^{45}$ As Prassl explains, '[t[he gig-economy business model is designed to divorce the fundamental entrepreneurial trade-off inherent in fully functioning markets: cost and risk are shifted onto workers, whilst the intermediaries get to enjoy the profits.' See Prassl, above n 1, p 86.

${ }^{46}$ On this, see section 4 below.
} 
and how frequently, their work tasks are performed. The effect of such measures is to constrain the task-oriented worker's freedom with respect to ongoing allocation of her human capital (at least while 'on the job'), such that one of the traditional positive payoffs from assuming selfemployed status becomes largely negated. ${ }^{47}$

On the other hand, in theory the principal positive payoff for workers of assuming taskoriented work (at least relative to orthodox employment) is the degree of 'off-the-job' freedom that it purportedly permits in the sense of enabling gig workers to acquire a varied 'portfolio' of income-generating work sources, thereby providing scope for diversification of their labour and consequent 'hedging' against firm-specific risk. ${ }^{48}$ However, while the notion of gig workers as 'portfolio' human capital investors ${ }^{49}$ might have a certain intuitive theoretical appeal, the realities of task-oriented work tend to paint a much bleaker picture in this regard. It has been found that the practical capacity of task-oriented workers to provide their services via

\footnotetext{
${ }^{47}$ See, eg the private transport operator Uber's widely-reported policies of prescribing specific types of vehicle that drivers are entitled to use for hires; providing specified routes for drivers to follow for particular hires and also a recommended pricing system that drivers are expected to follow; forcibly logging off its app any driver who declines three successive trips; and deactivating the accounts of drivers whose average passenger ratings fall below a specified threshold. See Uber v Aslam, above n 5.

${ }^{48}$ On the significance of firm-specificity (or otherwise) in determining the likelihood of human capital (and other productive assets) being coordinated on a hierarchical/firm as opposed to decentralised/market basis, see Malone et al, above n 15, at 486 .

${ }^{49}$ In theory there are certain common qualities of task-oriented work that would initially appear conducive to human capital diversification. For instance, task-oriented work is by its nature ordinarily generic or non-firmspecific, in the sense that the productive value of such work is more or less the same irrespective of the particular productive outlet that it is being deployed within. As explained above, task-oriented work is by nature also divisible into specific tasks or assignments (e.g. taxi journeys, delivery assignments or clerical tasks), which can readily be performed in substantial autonomy from other aspects of the enterprise in which the relevant worker's labour is being deployed. See Prassl, above n 1, p 77; Lobel, above n 13.
} 
multiple work platforms is dependent ultimately on the nature of the work that they are equipped to perform. While certain types of gig work such as virtual PA and IT-based administrative work are in general more susceptible to being part of a varied multi-job portfolio, this tends not to be the case for more geographically restricted forms of gig work and/or those that necessarily entail a direct physical interface with customers, such as taxidriving and courier work. Accordingly, those workers operating in the latter types of sector have tended to find themselves more exposed to the risk of adverse fluctuations in local labour (and, concomitantly, product) market conditions. ${ }^{50}$ Moreover, recent evidence (from 2017) has shown that, in the UK at least, the phenomenon of the diversified portfolio gig worker is by and large a fictional creation, with over $60 \%$ of UK-based gig workers (including three in four female gig workers) earning less than $£ 11,500$ per year from task-oriented work, and over $30 \%$ earning less than $£ 4,500$ per year from such work. ${ }^{51}$ Meanwhile, the findings of a recent (2018) government survey have revealed (inter alia) that the median annual income of gig economy workers in the UK is only $£ 375$, with $65 \%$ of respondents reported to have earned less than $5 \%$ of their total income over the past year from gig work. ${ }^{52}$

As a result, over $60 \%$ of UK-based gig workers - including $73 \%$ of gig workers aged between 31 and 54 years old - have been compelled to rely on more conventional forms of

\footnotetext{
${ }^{50}$ See HM Government, The Experiences of Individuals in the Gig Economy (February 2018), pp 34-36, available at

https://assets.publishing.service.gov.uk/government/uploads/system/uploads/attachment_data/file/679987/17110 7_The

${ }^{51}$ RSA, above n 30, pp 21, 28 (based on RSA/Ipsos MORI survey evidence).

${ }^{52}$ Department for Business, Energy \& Industrial Strategy, The Characteristics of those in the Gig Economy:

Final Report (February 2018), p 6, available at
}

https://assets.publishing.service.gov.uk/government/uploads/system/uploads/attachment_data/file/687553/The_c haracteristics of those in the gig economy.pdf 
work to supplement their limited income derived from task-oriented work alone. Indeed, a recent survey has revealed that the vast majority of gig workers in the UK work only 16 hours per week or less in this way, with half accepting less than one paid gig per month. ${ }^{53}$ The implication is that, at least in its present form and scale, the task-oriented labour market is largely incapable of providing gig workers with meaningful scope for inter-firm diversification of their human capital, thereby significantly restricting their capacity for effective risk-hedging at the individual firm level. ${ }^{54}$

\section{(b) On-demand ('casual') work}

So-called 'casual' or on-demand work arrangements, while often viewed as analogous to gig work in the above sense, are really a qualitatively different phenomenon altogether. In fact as will be demonstrated below, in their most extreme and well-known form today, namely socalled 'zero-hours' contracts, they are more akin to standard employment relations than taskoriented work. As in the case of task-oriented work, the time periods over which on-demand (and especially zero-hours) work will be made available tend not to be contractually specified in advance. Rather, as its name suggests, on-demand work is customarily offered on a purely ad hoc basis at the short-term (in many instances 'on-the-day') request of the employer. However, the key difference from task-oriented work is that, with on-demand work, the worker's person themselves is typically regarded as being committed to the work. Accordingly,

\footnotetext{
${ }^{53}$ Ibid, pp 19, 21, 25. See also Taylor, above n 2, p 25.

${ }^{54}$ This would appear to reaffirm Prassl's claim that '[i]ndividual workers are rarely in a good position to hedge against economic risk.' Prassl explains that whereas 'investors can easily minimize their exposure to risk by diversifying their bets and splitting their money across different assets ... it is rather hard to do the same with jobs.' See above n 1, p 131.
} 
the on-demand worker (like an orthodox employee) is usually paid for their labour generally as opposed to any specific discernible 'output' that their work produces.

The typical task-diffuseness of on-demand work (at least relative to task-oriented work) is attributable in large part to the inherent nature of the work itself, which - unlike many types of gig work ${ }^{55}$ - tends to be geographically-specific in the sense of needing to be performed in a specific physical location such as a shop, factory or warehouse. ${ }^{56}$ On-demand work is also, to varying extents, typically less remote or autonomous than task-oriented work in the sense that many common types of on-demand work - such as retail, customer service or storage work - are dependent on the coordinated interaction of cohesive groups of workers, whose collective marginal product is consequently worth more than the simple aggregate of each of their respective individual inputs (to the extent that the latter is even capable of reliable calculation).

Therefore although on-demand work has - like task-oriented work - been described as 'divisible' in nature ${ }^{57}$ it is divisible in a somewhat different sense. Whereas the latter type of work (as explained above) is divisible at the micro level of the prescribed worker task or output itself, the former kind of work is divisible in the slightly different sense that on-demand workers are compensated on an impromptu periodic (e.g. hourly or daily) basis rather than by way of integral compensation for their continuing labour generally (e.g. by way of a fixed annual salary). In both cases, therefore, the relevant work arrangement (on the supply side at least) exhibits a significantly greater degree of 'granularity' (or 'bittiness') than the orthodox employment relation as depicted in the Coasean model. ${ }^{58}$

\footnotetext{
${ }^{55}$ On this, see above $\mathrm{n} 51$ and accompanying text.

${ }^{56}$ This is what one commentator has referred to as the 'supply-demand collocation' of many traditional types of work. See Sundararajan, above n 22, p 169.

${ }^{57}$ See Haldane, above n 3, at 4 .

${ }^{58}$ On the notion of granularity of modern work practices generally, see ibid, 4-5; Sundararajan, above n 22 , p 27.
} 
In terms of the particular bundle of structural features that it typically exhibits, ondemand work tends to represent an even more lopsided apportionment (in the employer's favour) of the social costs and benefits of productive activity than task-oriented work. As in the case of task-oriented work, with on-demand work there is no employer obligation to provide a minimum level of continuing paid work throughout the duration of the work relation (hence the abovementioned use of the popular term 'zero-hours' to refer to the most extreme forms of such work arrangement ${ }^{59}$ ). Furthermore, whereas the task-oriented worker tends at least to have a reasonable degree of 'off the job' freedom with respect to when and also how frequently work tasks are performed; this is ordinarily not the case for the on-demand worker. Rather, the fact that the on-demand worker is generally expected (albeit often not formally required as $\operatorname{such}^{60}$ ) to be available for work during requested time periods ${ }^{61}$ significantly constrains the degree of control they have over the allocation of their human capital, both within the relevant working

\footnotetext{
${ }^{59}$ It has been recorded that, between 2010 and 2016, the percentage of the UK workforce employed on so-called 'zero hour' contracts increased from $0.6 \%$ to $3 \%$, with the result that almost 1 million workers now have this status. See Haldane, ibid, at 6.

${ }^{60}$ However, in certain reported instances of on-demand work an actual formal contractual requirement of ongoing work-availability has been found to exist, such as in the form of a clause to the effect that failure to accept an allocated assignment without good cause will constitute gross misconduct on the relevant worker's part. It has been noted that such provisions create a scenario where the worker is "permanently "on call"' and thus effectively prevented from taking on additional outside work, despite receiving no contractual guarantee of minimum hours from their employer in return. See House of Commons, Business, Innovation and Skills Committee, Employment practices at Sports Direct, Third Report of Session 2016-17 (2016), paras 13-15, at
} https://publications.parliament.uk/pa/cm201617/cmselect/cmbis/219/219.pdf

${ }^{61}$ See CIPD, above n 4, p 22. 
relationship and - moreover - outside of it. ${ }^{62}$ It follows that the on-demand worker is typically much more restricted than the task-oriented worker as regards her ongoing availability for additional paid work from other sources. ${ }^{63}$

From the perspective of the present analysis, a notable consequence of the above geographic and institutional constraints is that on-demand work is, at least in the standard case, necessarily even more firm-specific in nature than task-oriented work due to the practical incapacity of the typical on-demand worker to reallocate her labour to alternative productive outlets (at least without incurring significant displacement costs in doing so). This 'lock-in' propensity of on-demand work has the effect of significantly constraining (if not eradicating outright) the on-demand worker's practical capacity for human capital diversification and consequent risk-hedging, typically to an even greater extent than her task-oriented counterpart. $^{64}$

${ }^{62}$ The Taylor Review has notably recorded hearing of numerous instances in practice 'of [worker] flexibility not
being reciprocated [by employers], with a requirement to be available for work at very short notice, without any guarantee that work will actually be available.' See above n 2, p 43.

${ }^{63}$ Curiously, in a recent TUC survey of UK workers employed on zero-hours contracts, only $21 \%$ of respondents cited flexibility to work more than one job as their principal reason for being on such a contract. By far the most common factor cited by respondents in this regard was the simple lack of availability of other forms of work, thereby in effect compelling them to assent to such terms in order to secure any employment at all. See Trades Union Congress, Great Jobs with Guaranteed Hours: What do workers really think about 'flexible' zero-hours contracts? (December 2017), p 7, available at https://www.tuc.org.uk/sites/default/files/great-jobs-withguaranteed-hours_0.pdf

${ }^{64}$ This is notwithstanding the fact that the skills base of most on-demand workers will likely not comprise a significant level of 'hard' firm-specific human capital, in the sense of knowledge or competencies geared specifically to the unique products or processes of a particular employer firm. Even in the absence of such 'hard' attributes, an on-demand worker will still have - for most intents and purposes - a firm-specific relationship with a given employer if their practical capacity to provide work via other productive outlets is substantially 
Generally speaking, on-demand work is also even less advantageous for workers than task-oriented work when it comes to distributing the upside and downside aspects of residual business risk exposure. Like the task-oriented worker, the on-demand worker's anticipated rate of return on human capital is subject to continual variation in accordance with the prevailing level of demand for their labour. Insofar as demand for their labour at any one time is dependent - in turn - on corresponding fluctuations in relevant product market demand, it follows that the on-demand worker is likewise exposed directly to the residual business risk of their employer. ${ }^{65}$ Such residual risk exposure is especially pertinent in the case of zero-hours workers, who by definition lack any downside contractual insurance against intermittent market shocks. However, whereas the task-oriented worker at least enjoys the limited capacity (subject to continuing demand for the product(s) of her labour) to enhance her income via voluntary assumption of increased tasks; in the standard case of on-demand (and particularly zero-hours) work, the prerogative to determine a worker's current time allocation rests unilaterally with her employer. Furthermore, insofar as adverse variations in worker time allocation risk occasioning frequent material shortfalls in work income, the on-demand worker is similarly exposed to continuing human capital-redeployment costs in the form of the need to secure additional sources of labour, albeit (for reasons explained above) with a likely lesser degree of flexibility in this regard than her task-oriented counterpart.

Finally, it perhaps goes without saying that the on-demand worker ordinarily has no entitlement to influence either the general strategic direction of her employer's business, or its assumed level of enterprise risk exposure, via involvement in management or governance of

constrained. On the notion of worker 'lock-in' generally, see H Hansmann The Ownership of Enterprise (Cambridge, MA: Harvard University Press, 1996), pp 25-27; C Mayer Firm Commitment (Oxford: OUP, 2013), pp 150-52.

${ }^{65}$ BEIS, above n 2, p 38. 
the firm. This is in spite of the fact that, as a substantially open-ended contractor with no ex ante immunity against residual business risk exposure, the on-demand worker's risk-adjusted rate of return on human capital is (like that of her task-oriented counterpart) susceptible to unilateral variation in accordance with the prevailing risk appetite of their employer's management. Moreover, the on-demand worker's relatively limited capacity for diversification of her human capital (as remarked on above), for instance in less risky work outlets, arguably heightens her unilateral contractual vulnerability along with the consequent need for effective surrogate measures to compensate her in this regard.

In summary, then, the essential features of (i) task-oriented and (ii) on-demand work, when analysed from a Coasean firm-theory perspective, are set out - respectively - as follows (for purposes of comparison, the corresponding respective features of self-employment and orthodox employment are additionally restated below).

Table 2: INSERT TABLE 2 ABOUT HERE

\section{COMPENSATING FLEXIBLE LABOUR: A HYPOTHETICAL BARGAIN}

\section{PERSPECTIVE}

Although the above binary typology is intentionally crude and generalised, it is nonetheless effective in highlighting certain curious features of those hybridised work forms that are most commonly observed in practice. In short, it would appear that almost all the key disadvantageous (i.e. '0') features of self-employment and orthodox employment from a worker perspective are substantially replicated within the two main hybridised forms of those relations (that is, task-oriented and on-demand work). However, by contrast, it would seem that - with only very limited exception - the main advantageous (i.e. ' 1 ') aspects of self- 
employment and orthodox employment (for workers) do not tend to be replicated within the hybridised forms. The normative implication is that these hybridised forms are systematically sub-optimal, in the sense that the ensuing negative trade-offs for workers are rarely (if ever) compensated for effectively by way of corresponding contractual or other relational benefits.

Of course, in the (assumed) absence of material power imbalance and other impediments to efficient contracting by the parties concerned, such a skewed distribution of costs and benefits between employers and hybridised workers need not in itself constitute a socially sub-optimal outcome. Under such (idealised) bargaining conditions, ${ }^{66}$ the contracting parties would presumably be able to both 'price' and, if desired, mutually 'trade off' their respective entitlements in reaching a distributive outcome that maximises the joint surplus accruing from their productive activities. As a result, the initial (i.e. legal or pre-contractual) allocation of entitlements between them should be unimportant. ${ }^{67}$

\footnotetext{
${ }^{66}$ On the inherent counter-factuality of hypothetical bargaining models generally within legal scholarship, and their propensity to establish a normative case for social or regulatory outcomes different to those prevailing under (inferior) real world bargaining conditions, see D Charny 'Hypothetical Bargains: The Normative Structure of Contract Interpretation' (1991) 89 Michigan L Rev 1403, at 1415-16; R Dworkin ‘Why Efficiency?' (1980) 8 Hofstra L Rev 563; V Brudney 'Corporate Governance, Agency Costs, and the Rhetoric
} of Contract' (1985) 85 Columbia L Rev 1403, at 1415-16; MT Moore 'Private Ordering and Public Policy: The Paradoxical Foundations of Corporate Contractarianism (2014) 34 OJLS 693, at 712.

${ }^{67}$ On this, see generally RH Coase 'The Problem of Social Cost' (1960) J L \& Econ 1, esp at 8-15. For a comprehensive and varied collection of scholarly analyses of the so-called 'Coase Theorem' in this regard, see RA Posner and F Parisi (eds) The Coase Theorem Volume I: Origins, Restatements and Extensions (Cheltenham: Elgar, 2013) and The Coase Theorem Volume II: Criticisms and Applications (Cheltenham: Elgar, 2013). See also D Campbell and S Picciotto 'Exploring the Interaction between Law and Economics: The Limits of Formalism' (1998) 18 Leg Stud 249, at 251-53. 
Accordingly, if - to adopt a hypothetical example - subjecting a worker to pervasive employer direction and/or control is conducive to minimising her employer's costs of production $^{68}$ (e.g. by enabling quicker detection by the employer of reduced effort or 'shirking' ${ }^{69}$ on the worker's part), the employer will rationally seek to impose such an arrangement on the worker concerned. ${ }^{70}$ However the worker, far from being oppressed or exploited by this arrangement, will rather only rationally submit to the employer's terms if adequately compensated for doing so. For instance the worker might agree to accept reduced 'on the job' freedom in return for a correspondingly higher rate of pay from her employer. Moreover, such a voluntary trade-off is possible irrespective of the parties' initial legal position, which (at least in theory) can readily be varied in accordance with their rational individual preferences. $^{71}$

It follows that, so long as the anticipated cost-savings for the employer (from reduced worker shirking) exceed the compensatory wage increase demanded by the worker, the arrangement will produce a net gain for the employer. And, likewise, insofar as the worker values her promised wage increase more than the 'on the job' freedom she would otherwise

\footnotetext{
${ }^{68}$ For an influential understanding of efficiency (in a legal context) in terms of 'reducing the ongoing costs of organizing business through the corporate form', see R Kraakman et al The Anatomy of Corporate Law: A Comparative and Functional Approach, $3^{\text {rd }}$ ed (Oxford: OUP, 2017), p 2. See also Hansmann, above n 65, pp $21-22$.

${ }^{69}$ This term is attributable to EF Fama 'Agency Problems and the Theory of the Firm' (1980) 88 JPE 288, at 295.

${ }^{70}$ See MC Jensen and W Meckling 'Theory of the Firm: Managerial Behavior, Agency Costs and Ownership Structure' (1976) 3 JFE 305, at 308-10.

${ }^{71}$ On the (purported) function of the firm as a quasi-contractual mechanism for mitigating incidences of shirking and other agency costs arising from collective productive ventures, see AA Alchian and H Demsetz 'Production, Information Costs and Economic Organization' (1972) 62 AER 777.
} 
have enjoyed, the same arrangement is also conducive to a net gain for the worker. In this way, the contracting parties' respective preferences are brought into equilibrium in a manner that maximises their joint economic surplus, in the sense of the combined net value of their productive endeavour. $^{72}$

By the same token, requiring the notional worker to bear a significant degree of residual business risk - for instance, via a zero-hours contract or other flexible work arrangement - will be conducive to lower production costs for her employer, who will consequently be relieved of the 'holdover' cost of retaining superfluous labour during relative product market downturns. Seeking to impose such an arrangement on the worker will therefore likely be in the employer's interest. However, in response the rational worker will (in theory) ask for corresponding contractual compensation, such as a higher rate of pay to compensate her for the reduced riskadjusted value of her human capital, relative to what it would have been worth under an orthodox guaranteed-hours employment contract. At least, these are the distributive outcomes that we might expect to observe in the presence of idealised bargaining conditions: that is to say, full information and rational foresight on the part of the parties concerned, with no material disparities in their relative bargaining power. ${ }^{73}$ However, once we move away from those (unrealistic) neo-classical assumptions, and introduce the real-world phenomena of bounded

\footnotetext{
${ }^{72}$ As Coase explains, 'choosing between social arrangements within the context of which individual decisions are made, we have to bear in mind that a change in the existing system which will lead to an improvement in some decisions may well lead to a worsening of others', and therefore that '[i]n devising and choosing between social arrangements we should have regard for the total effect.' See Coase, above n 68, at 44.

${ }^{73}$ On this, see RH Coase, 'The New Institutional Economics' (1984) 140 JITE 229, at 231.
} 
rationality, informational incompleteness, uncertainty and material bargaining inequality into the contractual fold, ${ }^{74}$ a rather different picture emerges. ${ }^{75}$

In the former of the two hypothetical scenarios set out above, the worker who trades off her 'on the job' freedom in return for a higher rate of pay will likely be unable to foresee accurately the full ambit of tasks that her employer might seek to impose on her in future. Indeed, inherent in the very legal nature of employment - as a relatively complex and diffuse relational contract - is the likelihood that many of the precise obligations of the parties (and especially the employee) will fall to be determined on a post-contractual basis under varying factual circumstances. ${ }^{76}$ It is thus unrealistic to expect a worker to be able accurately to 'price' her expected level of commitment pre-contractually. In the majority of instances, though, it is arguably possible for the prospective worker to at least make a proximately accurate assessment of the likely nature and extent of her potential work tasks at the pre-contractual stage, such that ex ante pricing of her future human capital commitment - while by no means perfect - is nonetheless not necessarily frustrated as such. ${ }^{77}$

\footnotetext{
${ }^{74}$ See (inter alia) Coase, ibid; OE Williamson The Mechanisms of Governance (Oxford: OUP, 1996), pp 55-57; HA Simon 'Theories of Decision-Making in Economics and Behavioral Science' (1959) 49 AER 253; HA Simon
} 'A Behavioral Model of Rational Choice' (1955) 69 Q J Econ 99; AA Alchian 'Uncertainty, Evolution and Economic Theory' (1950) 58 JPE 211.

${ }^{75}$ In particular, it has recently been highlighted how the majority of notional employment 'agreements' in the UK today, including $86 \%$ of zero-hours work contracts, are not actually negotiated at all but rather take the form of employer-imposed standard form contracts, which prospective workers are presented with on a take-it-or-leave-it basis. See Bales et al, above n 9, at 50-51, citing data published in CIPD, above n 4.

${ }^{76}$ On the notion of relational contracting generally, see IR Macneil 'Contracts: Adjustment of Long-Term Economic Relations Under Classical, Neo-Classical, and Relational Contract Law' (1978) 72 Nw U L Rev 854.

${ }^{77}$ For an economic argument to this general effect, see OE Williamson and J Bercovitz 'The Modern Corporation as an Efficiency Instrument: The Comparative Contracting Perspective' in C Kaysen (ed) The American 
By contrast, the latter of the above two scenarios presents considerably greater difficulty from an ex ante pricing perspective. The problem is that, under real-world bargaining conditions, pre-contractual pricing mechanisms tend to be systematically ineffective as a means of compensation for residual business risk exposure. This is principally on account of the inherent uncertainty involved in quantifying the degree of potential downside risk involved. To take the above zero-hours contract scenario as a pertinent example: in a volatile product (and, concomitantly, labour) market environment the on-demand worker's potential future return on human capital could vary considerably, and could even be non-existent for significant periods of time. Under such turbulent conditions, determining an adequate level of ex ante (e.g. wagebased) compensation for the notional worker is thus rendered an intractable task. There consequently exists considerable scope for unilateral opportunism, insofar as the employer enjoys leeway to provide an ex ante level of compensation that is insufficient to compensate the flexible worker for the full extent of residual business risk to which she is ultimately exposed. The result is an uncompensated reduction in the latter's risk-adjusted rate of return on human capital.

Insofar as the employer's gains from the zero-hours work arrangement (in the form of reduced holdover costs) are won merely at the direct expense of the worker in the above way; it follows that, from a normative (economic) standpoint, the arrangement between the parties will be conducive to no net added value for society. ${ }^{78}$ However, even to the extent that adoption of a zero-hours work arrangement is conducive to a net social gain (in the sense that the employer's marginal benefit from the arrangement exceeds the worker's corresponding

Corporation Today: Examining the Questions of Power and Efficiency at the Century's End (Oxford: OUP, 1996), ch 10 .

\footnotetext{
${ }^{78}$ In technical terms, the relevant arrangement will thus be Kaldor-Hicks inefficient. See J Hicks 'The Foundations of Welfare Economics' (1939) 49 EJ 696.
} 
marginal cost), the ensuing outcome will still be socially sub-optimal if the real-world distribution of the surplus between the parties is significantly out of kilter with what it would have looked like in the absence of material uncertainty and relative power disparity. ${ }^{79}$

Of further concern, though, is the longer-term social cost of such a lopsided risk distribution in reducing the level of continuing trust that the worker is willing to repose in the employer, as manifested by the former party's willingness to commit her labour to the latter's cause beyond the most basic level elicited by her ex ante contractual obligations. ${ }^{80}$ This is because zero-hours and other divisible work arrangements lack the element of reciprocal 'give and take' that is implicit in the orthodox employment relation, in the sense that a fixed-wage employee is liable at various times to be both under- and over-compensated for their labour depending on prevailing market conditions, with the general expectation being that the parties will more or less break even over time. By contrast, on-demand (and especially zero-hours) work arrangements typically provide no credible assurance that such long-term 'evening-out' will occur. Consequently, the on-demand (and especially zero-hours) worker will likely be discouraged from rendering herself vulnerable to employer exploitation by unilaterally assuming any (extra-minimal) level of work commitment that is liable to go uncompensated. ${ }^{81}$ The outcome is a downward spiral in employer-worker trust; resulting in reduced worker productivity, higher employer production costs and, ultimately, a mutual net loss for the parties concerned.

\footnotetext{
${ }^{79}$ By contrast, in this instance the relevant arrangement, while Kaldor-Hicks efficient, will still be Pareto inefficient. On the latter notion, see ibid, at 700-01.

${ }^{80}$ On this generally, see MM Blair and LA Stout 'Trust, Trustworthiness and the Behavioral Foundations of Corporate Law' (2001) 149 U Pa L Rev 1735.

${ }^{81}$ Ibid, at 1750-53.
} 


\section{THE STRUCTURAL SIMILARITY BETWEEN FLEXIBLE WORK AND UNSECURED FINANCIAL INVESTMENTS}

Furthermore, it can be said that the position of the flexible worker, as an at-risk human capital investor, is in many ways structurally similar to that of an at-risk or unsecured financial investor. This is because, in an orthodox (i.e. guaranteed-hours) employment arrangement, the employee's continuing contractual assurance of minimal working hours is the functional analogue of collateral security in the case of debt finance. That is, insofar as it provides an ex ante buffer for the employee's committed human capital against exogenous market shocks, at least for the duration of the relevant employment relation. ${ }^{82}$

Indeed, the limitations of pre-contractual (e.g. price- or wage- based) measures as effective compensation for vulnerable or 'at-risk' investments have been well-documented within law and finance literature. ${ }^{83}$ In particular, it has been explained how fixed-interest debt

\footnotetext{
${ }^{82}$ Admittedly in the case of task-oriented workers the above analogy with at-risk financial investors might not appear entirely apt, insofar as the characteristic genericity and divisibility of much task-oriented work ordinarily enables gig workers to maintain a less committed (or locked-in) relationship with individual employers than in the case of orthodox employees. However, the functional analogy with the at-risk financial investor is predicated not on the assumption that the flexible worker's human capital is irrevocably committed to the employer firm (it typically is not), but rather on the premise that - albeit for different reasons - both parties are inherently incapable of acquiring effective insurance against residual business risk exposure via orthodox contractual means (in the former party's case due to the contractual unsecurability of their financial investment, and in the latter party's case due to the absence of any ex ante contractual guarantee of their allocated working hours).

${ }^{83}$ See eg O Hart 'Incomplete Contracts and the Theory of the Firm' (1988) 4 JL Econ \& Org 119; B Klein, RG Crawford and AA Alchian 'Vertical Integration, Appropriable Rents, and the Competitive Contracting Process' (1978) 21 JL \& Econ 297; OE Williamson Markets and Hierarchies: Analysis and Antitrust Implications (New York: Free Press, 1975).
} 
financing is an inherently unsuitable means of funding firm-specific or non-redeployable assets, whose insusceptibility to liquidation renders them ineffective for the purpose of collateral security. ${ }^{84}$ It follows that the creditor in this situation is exposed more or less entirely to the residual risk of debtor firm failure, which is impossible to quantify and price reliably by way of an ex ante contractual interest rate. ${ }^{85}$ Accordingly, the lender may instead have recourse to ex post 'settling-up' mechanisms such as 'event-of-default' clauses, which will function as a surrogate for comprehensive pre-contractual risk-pricing by enabling the creditor to revise certain aspects of her initial arrangement with the debtor (or potentially even terminate it outright) in response to specified post-contractual variations in the former party's initial risk exposure. ${ }^{86}$

Alternatively, in underwriting at-risk (i.e. contractually unsecurable) firm investments it may even be prudent for the relevant funder to dispense with debt finance altogether and instead acquire effective part-ownership of the firm itself by means of equity finance. From this perspective, equity capital could be regarded as the ultimate form of ex post settling-up mechanism insofar as it enables an at-risk investor to dispense entirely with the right to an ex ante fixed contractual rate of return on her capital. In its place is substituted: (i) the entitlement to appropriate a share of the firm's 'upside' residual profit as the effective price for assuming exposure to a portion of its 'downside' residual risk; and (ii) the supplementary entitlement to exercise a degree of control over the firm's management commensurate with the proportion of

\footnotetext{
${ }^{84}$ See Kelly and Parkinson, above n 40, at 120; Williamson, above n 75, pp 183-85.

${ }^{85}$ Likewise, the worker who acquires firm-specific human capital that cannot readily be redeployed to another use on the labour market puts themselves in a similar position to the lender in the above example. See Kelly and Parkinson, ibid, at 123-27.

${ }^{86}$ On this generally, see O Hart and J Moore 'Incomplete Contracts and Renegotiation' (1988) 56 Econometrica 755.
} 
residual risk assumed. In this way, the at-risk financial investor is able to mitigate her susceptibility to post-contractual exploitation by bargaining for quasi-ownership rights over the investee firm itself, which theoretically enables her to influence directly the risk-adjusted rate of return on her committed capital on a continuing basis. ${ }^{87}$

It therefore follows that, just as the absence of effective security (e.g. in the case of a firm-specific, non-redeployable investment) is liable to elicit the need for compensatory post-contractual protections (including quasi-ownership rights) on the part of an at-risk financial investor; so too is the absence of contractually-assured working hours prone to engender the same in the case of a flexible worker (as an at-risk human capital investor) ${ }^{88}$ In particular, since - as explained above - ex ante pricing mechanisms (e.g. fixed contractual wage rates) are technically incapable of compensating at-risk human capital investors for their residual business risk exposure and ancillary costs, ${ }^{89}$ there arises the corresponding need for surrogate ex post settling-up mechanisms in the case of on-demand and other flexible workers. Such measures must be designed to facilitate effective post-contractual responses by workers

\footnotetext{
${ }^{87}$ See Williamson, above n 75, pp 184-85; S Grossman and O Hart 'The Costs and Benefits of Ownership: A Theory of Vertical and Lateral Integration' (1986) 94 JPE 691; EF Fama and MC Jensen 'Separation of Ownership and Control' (1983) 26 JL \& Econ 301, at 302-03.

${ }^{88}$ On the notion of at-risk human capital generally, see Kelly and Parkinson, above n 40, at 123-27; Blair, above n 40, pp 249-52; RG Rajan and L Zingales 'Power in a Theory of the Firm' (1998) 113 Q J Econ 387.

${ }^{89}$ For this reason, there is cause for scepticism as to the likely effectiveness of Taylor's recommendation for an additional pay premium on the National Living Wage and National Minimum Wage applicable to any hours that an individual is requested to work over and above their contractually guaranteed working hours. See Taylor, above $\mathrm{n} 2$, p 44; HC Committees, above $\mathrm{n}$, paras 18-21. Without any supplementary contractual guarantee of reasonable work hours, an hourly wage premium alone is incapable of mitigating a flexible worker's vulnerability to ex post exploitation in the sense outlined above, at least in the absence of additional post-contractual settling-up mechanisms on their part.
} 
to attempted adverse variations in their risk-adjusted rate of return on human capital; the aim being to bring real-world distributional outcomes of flexible work closer to the notionally optimal outcomes that would ensue under idealised bargaining conditions, where accurate precontractual pricing of risk exposure is technically feasible.

Indeed, insofar as flexible workers are - like underwriters of unsecurable financial investments - exposed more or less entirely to the (contractually-irreducible) residual business risk of the enterprise in which their capital is invested, it follows by analogy that flexible workers will only adequately be compensated for the full extent of their commitment to the employer firm by means of outright quasi-ownership rights therein. Ideally, such rights should include: (i) the entitlement to compensatory 'upside' profit-sharing rights commensurate with their downside residual risk exposure, by means of a cooperative firm ownership structure ('coop' $)^{90}$ or employee share ownership plan ('ESOP'), ${ }^{91}$ and also (ii) the supplementary entitlement to influence the firm's overall business strategy and risk appetite by means of

\footnotetext{
${ }^{90}$ In this regard, an encouraging recent development has been the emergence of the so-called 'platform cooperativism' movement, denoting a growing trend towards the use of worker ownership structures in the gig economy. Although the platform co-op sector is at present still in a relatively fledgling phase of development (and also largely, albeit not wholly, US-specific), the future development of such undertakings on a material scale in the UK is by no means an unrealistic possibility. See RSA, above n 30, pp 53-54; Sundararajan, above $n$ 22, pp 169-99; T Scholz and N Schneider (eds) Ours to Hack and to Own: The Rise of Platform Cooperativism, a New Vision for the Future of Work and a Fairer Internet (New York: OR Books, 2017).

${ }^{91}$ On this generally, see Hansmann, above n 65, pp 105-08; and, in the specific context of the gig (or 'sharing') economy, see Sundararajan, ibid, pp 199-200.
} 


\section{The Gig Economy}

employee information and consultation (ICE) rights, ${ }^{92}$ partial board representation (or 'codetermination' $)^{93}$ and/or other high-level managerial decision-making rights. ${ }^{94}$

Accordingly, via profit-sharing rights flexible workers can be effectively compensated for their residual risk bearing function vis-à-vis the firm. Furthermore, via co-decision-making rights in the firm, flexible workers will formally be in a position to exert influence over some

\footnotetext{
${ }^{92}$ While a statutory ICE framework exists in the UK, there is no default employer obligation to provide ICE. Rather, initiation of ICE in any instance is (at the time of writing) conditional on the formal written request of at least $10 \%$ of employees of the relevant undertaking, which in any event must employee at least 50 persons. See Employment Relations Act 1994, s 42; Information and Consultation of Employees Regulations (ICER) 2004
} (2004/3426), Regs 3(1)(a), 7(2), Sch 1. Notably, both the Taylor Review and subsequent House of Commons Committees' Report into modern employment practices have called for reduction of the statutory triggering threshold from $10 \%$ to $2 \%$ of a relevant undertaking's workforce. The latter report further advocates that this figure should include those workers not classed as full 'employees' in the formal statutory sense. See Taylor, above n 2, p 20; HC Committees, above n 7, paras 44-45. Lamentably, the UK government has since expressly refrained from committing itself to reducing the statutory triggering threshold for initiating workplace ICE or to extending the ICE framework to non-standard workers, pending further consultation on whether there exists a sufficient 'appetite' for such reforms. See BEIS, above n 2, p 44.

${ }^{93}$ On this issue Taylor curiously opted to refrain from further enquiry, stating only that '[w]e do not have a strong view on whether workers should be directly represented on company boards, as they are in some other countries, or whether other solutions would work better in a British context.' In a similarly cautious vein, the House of Commons Business, Energy and Industrial Strategy (BEIS) Committee has opined that, while 'we encourage more companies to appoint workers on boards ... [w]e are not minded to recommend the compulsory requirement for companies over a certain size to include a worker on board.' See Taylor, above n 2, p 52; BEIS Committee, 'Corporate governance', Third Report of Session 2016-17, paras 146-47, available at https://publications.parliament.uk/pa/cm201617/cmselect/cmbeis/702/702.pdf

${ }^{94}$ For a critical appraisal of worker participation mechanisms in corporate governance generally, see Hansmann, above n 65, pp 105-12. 
of the key variables determining their prevailing rate of return on human capital. ${ }^{95}$ Under the idealised conditions of the above hypothetical bargaining model it is thus possible to envisage a dual paradigm of work emerging, whereby human capital suppliers opt either for the relative contractual insulation from extraneous risk that an orthodox employment arrangement provides; or, alternatively, for the lesser insulation but correspondingly greater quasiproprietary entitlement that a flexible work arrangement offers. In this way, prospective workers would be in a position rationally to weigh up the respective costs and benefits of each type of arrangement in determining which particular trade-off is more amenable to them. Meanwhile, employers would be significantly constrained as regards their capacity to offer ondemand and other flexible work. This is because such arrangements would only rationally be assumed by workers where employers are willing to cede to workers the level of proprietary and governance influence that is needed to make flexible work mutually beneficial, at least in comparison to orthodox guaranteed-hours work arrangements.

Of course, it is one thing to claim that such a dual structure of work is notionally ideal or optimal from an economic efficiency perspective, and quite another to suggest that it is likely to emerge in practice, at least without some form(s) of mandatory regulatory compulsion. Indeed, it is strongly arguable that the likely persistence of the various real-world obstacles to efficient employer-worker bargaining alluded to above necessitates the advancement of a

\footnotetext{
${ }^{95}$ Notably, the most recent edition of the UK Corporate Governance Code expressly recommends that Premium Listed establish a method for gathering the views of their workforce whether in the form of: (i) a director appointed from the workforce, (ii) a formal workforce advisory panel, or (iii) a designated non-executive director in this regard. The Code further recommends that directors' annual reports should explain how the board has engaged with the company's workforce and other stakeholders, and how such interests have influenced the board's decision-making. See FRC, UK Corporate Governance Code (July 2018), Provision 5, available at https://www.frc.org.uk/directors/corporate-governance-and-stewardship/uk-corporate-governance$\underline{\text { code }}$
} 
compelling normative case for the effective 'correction' of what is fundamentally a structural labour market failure: that is, the systematic adverse selection by flexible or non-standard workers of effective proprietary and/or governance compensation for their residual risk bearing function within the firm. ${ }^{96}$ The task of identifying the specific regulatory measures that might be conducive to fulfilling this corrective function is beyond the scope of the present paper. For immediate purposes, though, the recent UK Labour Party proposals to require: (i) that companies employing at least 250 persons progressively allocate up to $10 \%$ of their share capital to a special 'inclusive ownership fund' (or 'IOF') for the collective benefit of their workforce, ${ }^{97}$ (ii) that at least one-third of seats on the boards of directors of companies employing 250 or more persons are allocated to worker representatives, ${ }^{98}$ and (iii) that worker pre-emption rights are created vis-à-vis shares in companies that are subject to prospective acquisition, ${ }^{99}$ would together seem like a constructive starting point for this discussion at the very least.

\footnotetext{
${ }^{96}$ For a similar argument to this effect in respect of systematic adverse selection by shareholders of effective corporate governance protections, and the ensuing normative case for mandatory state regulation in this regard, see FE Easterbrook and DR Fischel, 'The Corporate Contract' (1989) 89 Colum L Rev 1416, at 1433- 36; JN Gordon, 'The Mandatory Structure of Corporate Law' (1989) 89 Colum L Rev 1549, at 1554. On this, see also CR Sunstein, 'Legal Interference with Private Preferences' (1986) 53 U Chi L Rev 1129; M Moore, Corporate Governance in the Shadow of the State (Oxford: Hart, 2013), pp 238-42.

${ }^{97}$ R Syal, 'Employees to be handed stake in firms under Labour plan', The Guardian, 24 September 2018.

${ }^{98}$ A Cowburn, 'Workers to make up one third of company board members under Labour, Corbyn vows', The Independent, 23 September 2018. See also M Lawrence, Corporate Governance Reform: Turning business towards long-term success (IPPR Discussion Paper, July 2017), p 3.

${ }^{99}$ See Labour Party Manifesto: Creating an Economy that Works for All (Widening Ownership of our Economy) (May 2017), available at https://labour.org.uk/manifesto/creating-economy-works/\#first
} 


\section{The Gig Economy}

\section{CONCLUSION}

Irrespective of one's personal opinion on the social desirability (or otherwise) of the gig economy and flexible work practices in general, at least one thing would appear certain: both for legal scholars and social commentators more broadly, this topic is unlikely to recede into the shadows any time soon. At the time of writing, the widely-reported Uber $v$ Aslam case $\mathrm{e}^{100}$ on the proper legal classification of gig economy operatives awaits the next stage of its hearing before the UK Supreme Court, ${ }^{101}$ as similar litigation involving other well-known gig platform operators likewise rumbles on. ${ }^{102}$ In the policymaking realm, meanwhile, the UK government looks set to implement many of the recommendations of the 2017 Taylor Review ${ }^{103}$ and House of Commons Committees' Report ${ }^{104}$ on modern employment practices, ${ }^{105}$ which will likely have significant repercussions for the future shape and scope of the UK's gig-based and ondemand labour market sectors. ${ }^{106}$ And, even in the traditionally staid and prosaic world of UK corporate governance regulation, landmark change has recently occurred in the guise of the new (as of July 2018) UK Corporate Governance Code recommendation for the involvement of workers - and, in particular, casual and other non-standard members of the workforce - in the governance of Premium-Listed companies. ${ }^{107}$

\footnotetext{
${ }^{100}$ See above $\mathrm{n} 5$.

${ }^{101}$ S Butler, 'Uber loses appeal over driver employment rights’, The Guardian, 20 December 2018.

${ }^{102}$ O Bowcott 'Gig economy: heating engineer wins claim against Pimlico Plumbers', The Guardian, 13 June 2018.

${ }^{103}$ See above $\mathrm{n} 2$.

${ }^{104}$ See above $\mathrm{n} 7$.

${ }^{105}$ See above $\mathrm{n} 8$.

${ }^{106} \mathrm{R}$ Syal and H Stewart, 'Workers get new rights in overhaul but zero-hours contracts remain', The Guardian, 17 December 2018.

${ }^{107}$ See above $\mathrm{n} 98$.
} 
Since the ongoing judicial and regulatory developments in this field are likely to be subject to the intense scrutiny of both employment law and corporate governance specialists for the foreseeable future, the present author has opted to refrain from venturing into this particular field of enquiry. Instead, this article has been designed for the purpose of bringing alternative inter-disciplinary insights, which have traditionally been more at home within the field of corporate law, to bear on the notionally separate factual domain of contemporary employment practices. Indeed, although corporate and employment law are - academically speaking at least - two traditionally autonomous fields of enquiry with relatively limited crossover of ideas and insights, ${ }^{108}$ this belies the reality of how the industrial relations world operates. In practice, the significant and complex interactions between a firm's businessorganisational structure and work practices mean that, for scholars and students on either side of the artificial corporate/employment law divide, there is much to be gained from the mutual sharing of ideas and perspectives. ${ }^{109}$

Above all, it is the present author's view that many of the core arguments and insights from law and economics which are familiar to corporate law scholars are applicable just as readily to the employment law and industrial relations context. Moreover, this stands true nowhere more so than in the field of flexible or non-standard work practices, where some key insights from the economic analysis of law - and, in particular, the Coasean theory of the firm - have a great deal to add to the existing body of received legal knowledge and opinion.

\footnotetext{
108 On the traditional status of employment and corporate/company law as mutually autonomous academic domains with limited reciprocal crossover of ideas and insights, see A Carse and W Njoya 'Labour Law as the Law of the Business Enterprise' in A Bogg, C Costello, ACL Davies and J Prassl (eds) The Autonomy of Labour Law (Oxford: Hart, 2015), ch 13, at 313; Lord Wedderburn of Charlton, The Future of Company Law: Fat Cats, Corporate Governance and Workers (Liverpool: IER, 2004), p 41.

${ }^{109}$ M Moore 'Bridging the Gap Between Labour Law and Company Law' (2015) 44 ILJ 425.
} 
This article aspires to provide additional conceptual fuel for continuing scholarly and policy debates in the field. In particular, it is hoped that the above insights will help to equip those intuitively uncomfortable with the social outcomes of many controversial modern work practices with a broader array of normative arguments on which to draw in expressing their opposition and key concerns. At the same time, as is the case when critiquing any innovation or phenomenon that holds out the potential for significant socio-economic advancements, one should remain alert to the risk of throwing out the baby with the bathwater. ${ }^{110}$

\footnotetext{
${ }^{110}$ As Coase has observed, ' $[$ t]he cost of exercising a right (or using a factor of production) is always the loss which is suffered elsewhere in consequence of the exercise of that right', such that 'we have to bear in mind that a change in the existing system which will lead to an improvement in some decisions may well lead to a worsening of others.' Above n 68, at 44.
} 